\title{
The Protective Role of Natriuretic Peptide Receptor 2 against High Salt Injury in the Renal Papilla
}

George J. Dugbartey, ${ }^{*}$ Breandan Quinn, ${ }^{*}$ Lingfeng Luo, ${ }^{*}$ Deanne M. Mickelsen, ${ }^{*}$ Sara K. Ture, ${ }^{*}$ Craig N. Morrell, ${ }^{*}$ Jan Czyzyk, Marvin M. Doyley, ${ }^{\ddagger}$ Chen Yan, ${ }^{*}$ Bradford C. Berk, ${ }^{* \S}$ and Vyacheslav A. Korshunov*

From the Aab Cardiovascular Research Institute, ${ }^{*}$ the Department of Electrical and Computer Engineering, ${ }^{\ddagger}$ and the Department of Medicine, ${ }^{\S}$ Neurorestoration Institute, Hajim School of Engineering and Applied Sciences, University of Rochester, Rochester, New York; and the Department of Laboratory Medicine and Pathology, ${ }^{\dagger}$ University of Minnesota, Minneapolis, Minnesota

\author{
Accepted for publication \\ May 28, 2019. \\ Address correspondence to \\ Vyacheslav A. Korshunov, \\ Ph.D., Aab Cardiovascular \\ Research Institute, University \\ of Rochester School of Medi- \\ cine and Dentistry, $601 \mathrm{Elm}-$ \\ wood Ave, Box CVRI, \\ Rochester, NY 14642; or \\ Bradford C. Berk, M.D., Ph.D., \\ Neurorestoration Institute, Uni- \\ versity of Rochester, University \\ of Rochester Medical Center, \\ 601 Elmwood Ave, Box URNI, \\ Rochester, NY 14642. E-mail: \\ slava_korshunov@urmc. \\ rochester.edu or bradford \\ berk@urmc.rochester.edu.
}

\begin{abstract}
Mutations in natriuretic peptide receptor 2 (Npr2) gene cause a rare form of short-limbed dwarfism, but its physiological effects have not been well studied. Human and mouse genetic data suggest that Npr2 in the kidney plays a role in salt homeostasis. Herein, we described anatomic changes within renal papilla of $\mathrm{Npr} 2$ knockout $\left(\mathrm{Npr}^{-/-}\right)$mice. Dramatic reduction was found in diuresis, and albuminuria was evident after administration of $1 \% \mathrm{NaCl}$ in drinking water in $\mathrm{Npr}^{-/-}$and heterozygous $\left(\mathrm{Npr}^{+/-}\right)$mice compared with their wild-type $\left(\mathrm{Npr}^{+/+}\right)$littermates. There was indication of renal epithelial damage accompanied by high numbers of red blood cells and inflammatory cells (macrophage surface glycoproteins binding to galectin-3) and an increase of renal epithelial damage marker ( $\mathrm{T}$-cell Ig and mucin domain 1) in $\mathrm{Npr}^{-/-}$mice. Addition of $1 \% \mathrm{NaCl}$ tended to increase apoptotic cells (cleaved caspase 3 ) in the renal papilla of $\mathrm{Npr}^{-/-}$mice. In vitro, genetic silencing of the Npr2 abolished protective effects of C-type natriuretic peptide, a ligand for Npr2, against death of M-1 kidney epithelial cells exposed to $360 \mathrm{mmol} / \mathrm{L} \mathrm{NaCl}$. Finally, significantly lower levels of expression of the NPR2 protein were detected in renal samples of hypertensive compared with normotensive human subjects. Taken together, these findings suggest that Npr2 is essential to protect renal epithelial cells from high concentrations of salt and prevent kidney injury. (Am J Pathol 2019, 189: 1721-1731; https://doi.org/10.1016/j.ajpath.2019.05.020)
\end{abstract}

The natriuretic peptide (NP) family in mammals comprises three structurally homologous but genetically distinct peptides, the atrial NP, brain NP, and C-type NP (CNP). These peptides have been suggested to be involved in blood pressure (BP) regulation, fluid and electrolyte balance, and cardiovascular homeostasis. ${ }^{1-5}$ Both atrial NP and brain NP are mainly produced in atrial and ventricular cardiomyocytes, whereas CNP is found in a variety of tissues and acts locally in an autocrine and paracrine manner. ${ }^{6}$ Atrial NP and brain NP have high affinity for NP receptor A (Npr1; alias NPR-A), whereas CNP binding is limited to NP receptor B (Npr2; alias NPR-B). ${ }^{7,8}$ Binding of CNP to $\mathrm{Npr} 2$ increases the level of a second messenger, cGMP, which, in turn, activates protein kinase GI and phosphorylates target proteins, ultimately leading to regulation of a variety of physiological processes, including smooth muscle cell relaxation. ${ }^{9}$

Homozygous loss of function in the human NPR2 has been identified in patients with a rare form of short-limbed dwarfism called acromesomelic dysplasia, type

Supported in part by the University of Rochester Award 2016 (V.A.K. and M.M.D.) and NIH grants R01 HL134910 (C.Y.) and R01 HL062826 (B.C.B.)

Disclosures: V.A.K. received research support from Novartis Pharmaceuticals Corp.

Current address of G.J.D., Department of Pharmacology and Toxicology, School of Pharmacy, College of Health Sciences, University of Ghana, Accra, Ghana. 
Maroteaux. ${ }^{10}$ Homozygous deletion of $\mathrm{Npr} 2$ in mice $\left(\mathrm{Npr}^{-/-}\right)$caused dwarfism and female sterility. ${ }^{11}$ Mutations in the human NPR2 gene were associated with essential hypertension in a Japanese population. ${ }^{12}$ Genetic studies between $\mathrm{C} 57 \mathrm{BL} / 6 \mathrm{~J}$ and $\mathrm{A} / \mathrm{J}$ inbred mouse strains mapped a Bpq3 locus on chromosome 4, and suggested $N p r 2$ as a candidate for $1 \% \mathrm{NaCl}-$ induced BP variation. ${ }^{13}$ Endothelial-specific deletion of $C N P$ in mice demonstrated a pivotal role for CNP in BP homeostasis, although it appeared that signaling did not involve Npr2 receptor. ${ }^{14}$ It is likely that renal $\mathrm{Npr} 2$ plays an important role in kidney functions because it is widely expressed in several renal structures, including the glomeruli, tubules, and microvasculature. ${ }^{15,16}$ In this study, we investigated the effects of $\mathrm{Npr} 2$ gene deletion on renal structure and function in response to $1 \% \mathrm{NaCl}$ water intake.

\section{Materials and Methods}

\section{Animals}

The $N p r 2^{\text {tm1Gar} / J ~ b r e e d i n g ~ p a i r ~(s t o c k ~ n u m b e r ~ 007658) ~ w a s ~}$ obtained from The Jackson laboratory (Bar Harbor, ME). Genotyping was performed as described before. ${ }^{11}$ Briefly, mice that carry heterozygous alleles $\left(\mathrm{Npr}^{+/-}\right)$had two bands, whereas one band was detected in wild-type $\left(\mathrm{Npr}^{+/+}\right.$; 490 bp) or knockout $\left(\mathrm{Npr}^{-/-} ; 234\right.$ bp) littermates (Figure 1A) with a robust dwarfism phenotype. ${ }^{11}$ A 12-hour light/dark cycle was maintained (lights on at $6 \mathrm{Am}$, lights off at 6 PM) for animal housing. Mice had free access to chow and water. Experimental mice were given regular chow and $1 \% \mathrm{NaCl}$ in drinking water for 2 weeks, as originally reported. ${ }^{13}$ The study was approved by the University of Rochester (Rochester, NY) Animal Care Committee in accordance with the Guide for the Care and Use of Laboratory Animals. ${ }^{17}$

\section{Renal Cell Culture}

The M-1 ATCC cell line (ATCC, Manassas, VA) was maintained at $70 \%$ to $80 \%$ confluency in 1:1 Dulbecco's modified Eagle's and Ham's F12 medium with $120 \mathrm{mmol} /$ $\mathrm{L} \mathrm{NaCl} .^{18} \mathrm{M}-1$ cells were exposed to various concentrations of $\mathrm{NaCl}(120$ to $600 \mathrm{mmol} / \mathrm{L})$ in the medium for 1 hour, as before. ${ }^{19}$ The $N p r 2$ gene was silenced with siRNA, or a negative control confirmed expression of the $N p r 2$ and Gapdh using mouse primers (Integrated DNA Technologies, Skokie, IL) in the M-1 cells by real-time quantitative RT-PCR (CFX Connect; Bio-Rad, Hercules, CA). M-1 cells were pretreated with $100 \mathrm{nmol} / \mathrm{L}$ CNP (SigmaAldrich, St. Louis, MO) or phosphate-buffered saline (PBS) and exposed to $360 \mathrm{mmol} / \mathrm{L} \mathrm{NaCl}$ medium for 1 hour. Dead cells were stained with trypan blue, and images were captured by the EVOS FL Auto Imaging System (Thermo Fisher Scientific, Waltham, MA). Relative expression of live over dead cells was measured using
ImagePro Analyzer software version 6.2.1 (Media Cybernetics, Rockville, MD).

\section{Hematology}

Peripheral blood was collected via orbital bleeding into EDTA-coated tubes under isoflurane anesthesia, as before. ${ }^{20}$ Hematological parameters and peripheral blood cell count were measured in $\mathrm{Npr} 2$ mice using an automated cell counter (VetScan HM5; Abaxis, Union City, CA).

\section{Ultrasound Measurement of Kidneys in Npr2 Mice}

Renal artery and heart hemodynamic profiles and threedimensional imaging of the right kidney were acquired with a high-resolution Vevo2100 ultrasound system (FUJIFILM VisualSonics, Toronto, ON, Canada), as described before. $^{21,22}$ FUJIFILM VisualSonics Vevo LAB analysis software version 1.6.0 was used to calculate hemodynamic volume and percentage vasculature measurements.

\section{Blood Pressure Measurements in Npr2 Mice}

$\mathrm{BP}$ was measured in isoflurane anesthetized $\mathrm{Npr} 2$ mice, as recently reported. ${ }^{23}$ Briefly, a $1 \mathrm{~F}$ Mikro-tip transducer (Millar Instruments, Houston, TX) was placed in the left femoral artery and advanced into the descending aorta for recordings of the BP and heart rate. Parameters were analyzed using LabChartPro software version 7 (AD Instruments, Sydney, Australia).

\section{Kidney Functions in Npr2 Mice}

Details of urine collection, measurements of urine albumin, and fluid intake were previously described. ${ }^{21}$ Briefly, fluid intake and urination were measured for 24 hours in metabolic cages (Nalgene, North Las Vegas, NV) at baseline and 2 weeks after $1 \% \mathrm{NaCl}$. Proteinuria was determined by the ratio of albumin $(\mu \mathrm{g}) /$ creatinine $(\mathrm{mg})$, as was standardized for mice. ${ }^{24}$ Peripheral blood was collected via cardiac puncture of anesthetized animals. The level of cGMP (Enzo Life Sciences, Farmingdale, NY) or creatinine (Abcam, Cambridge, UK) in the plasma was quantified by using enzyme-linked immunosorbent assay kits. FluostarOptima version 2.20R2 (BMG LabTech, Cary, NC) was used to measure urine and plasma samples, and concentrations were calculated on the basis of a standard curve.

\section{Histology and Immunohistochemistry in Npr2 Mice}

At the time of termination, mice were perfused and fixed with $10 \%$ paraformaldehyde in sodium phosphate buffer (pH 7.0). Bones were also collected and underwent decalcification with $0.5 \mathrm{~mol} / \mathrm{L}$ EDTA before tissue processing, as before. ${ }^{25}$ Paraffin-embedded kidney sections 


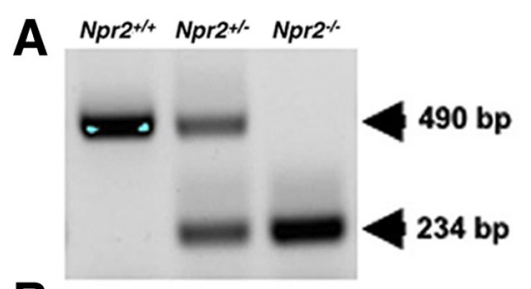

B
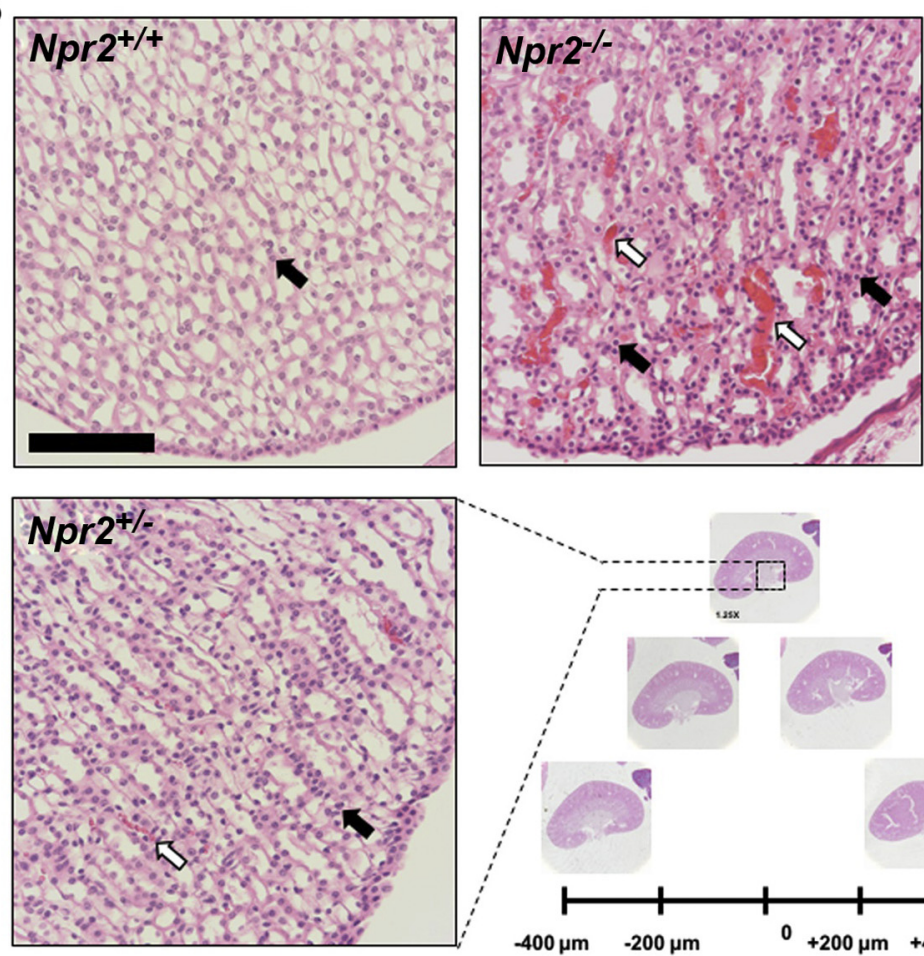
$\mathrm{Npr}^{-1-}$. Scale bar $=100 \mu \mathrm{m}(\mathbf{B})$.
Figure 1 Deletion of the Npr2 gene leads to renal papilla abnormality. A: A representative gel shows results of genotyping Npr2 wild-type $\left(\mathrm{Npr}^{+/+}\right)$, heterozygous $\left(\mathrm{Npr}^{+/-}\right)$, and knockout $\left(\mathrm{Npr}^{-/-}\right)$littermates. Teal markings are PCR products in bp. B: A quantification strategy of series of kidney sections every $200 \mu \mathrm{m}$. Dotted boxed area highlights a portion of a magnified renal papilla. White arrows point to blood in renal papilla. Black arrows point to nuclei in renal papilla. C: Quantification of nuclei area in renal papilla. D: Quantification of blood area in renal papilla. Black bars are $\mathrm{Npr}^{+/+}$mice. Gray bars are $\mathrm{Npr}^{+/-}$mice. White bars are $\mathrm{Npr}^{-/-}$mice. Data are expressed as means \pm SEM $(\mathbf{C}$ and $\mathbf{D}) . n=5$ per group $(\mathbf{C}$ and $\mathbf{D}) .{ }^{*} P<0.05$ versus $\mathrm{Npr}^{+/+}{ }^{\dagger} ;{ }^{\dagger} P<0.05$ versus

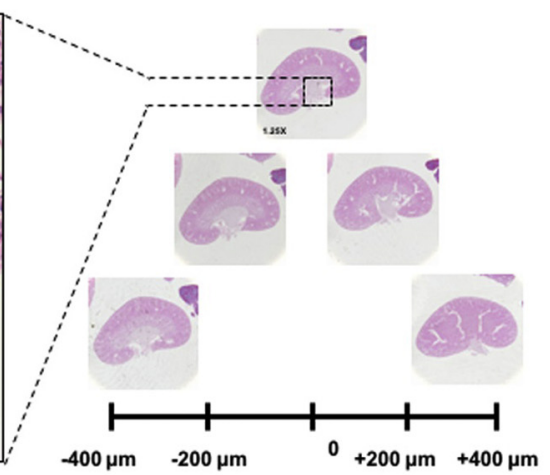

C
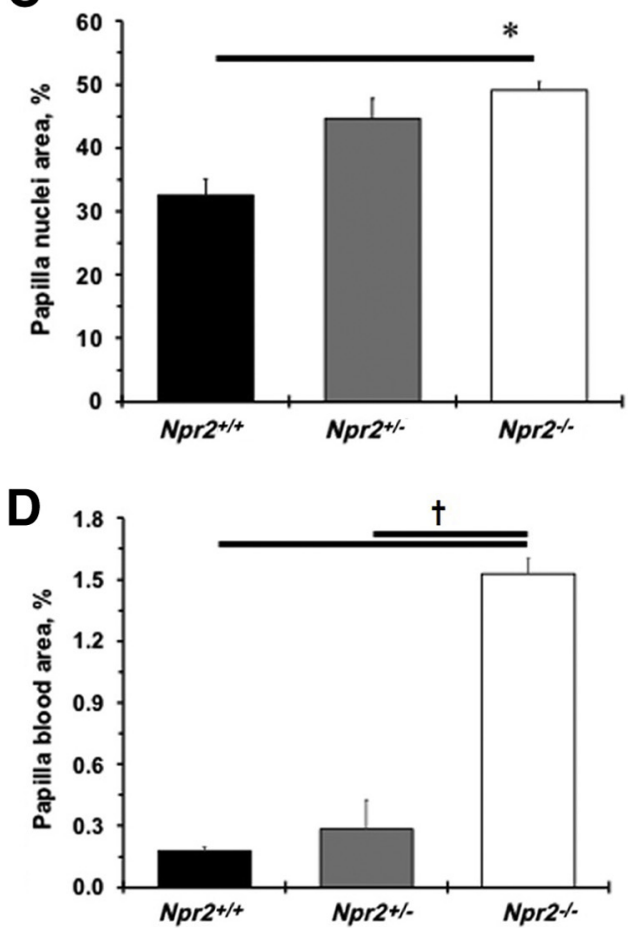

were cut in series every $200 \mu \mathrm{m}$ through the tip of the renal pelvis (Figure 1B). For general histology, crosssections of bones and kidneys were stained with hematoxylin and eosin in autostainer XL (Leica, Wetzlar, Germany). For immunohistologic evaluation, crosssections of kidneys were incubated with hydrous $3 \%$ $\mathrm{H}_{2} \mathrm{O}_{2}$ and followed by an antigen retrieval in a Decloaker buffer ( $\mathrm{pH}$ 6.0; Biocare, Pacheco, CA) with high temperature and pressure. The sections were double stained with rat anti-mouse macrophage surface glycoproteins binding to galectin-3 (Mac-2; dilution 1:15,000; Cedarlane, Burlington, ON, Canada) and rabbit anti-mouse Tcell Ig and mucin domain 1 (TIM-1; dilution 1:5000; Thermo Fisher Scientific) antibodies, as recently reported. $^{21}$ Rabbit antibodies against cleaved caspase 3 (dilution 1:100; Cell Signaling, Danvers, MA) and Npr2 (dilution 1:100; Abcam) were used, incubated overnight at $4{ }^{\circ} \mathrm{C}$, and followed by application of horseradish peroxidase or alkaline-phosphate polymers (Biocare). A secondary goat anti-rabbit antibody (dilution 1:400; Vector Laboratories, Burlingame, CA) with ABC kit (Vector Laboratories) was used to detect NPR2 in humans. Samples were counterstained with hematoxylin or methyl green. Images were captured by SPOT INSIGHT
FireWire camera (Diagnostic Instruments, Sterling Heights, MI) and analyzed in ImagePro Analyzer software (Media Cybernetics). A percentage of positive cells or staining was determined in relation to counterstained cells or background area within defined area of the kidney (renal medulla or papilla), as reported before. ${ }^{26}$

\section{Human Samples}

Cross-sections of deidentified human kidney biopsies from hypertensive or normotensive subjects were obtained with the approval from the University of Rochester School of Medicine and Dentistry Research Subjects Review Board (RSRB00073722).

\section{Statistical Analysis}

Results are reported as means \pm SEM. Statistical tests were performed using JMP13.0.0 (SAS, Cary, NC). Differences between three or more groups were analyzed by one-way analysis of variance, followed by post-hoc Tukey-Kramer honestly significant difference test. $P<0.05$ was regarded as significant. 
Table 1 Hematological Parameters across $\mathrm{Npr}^{+/+}, \mathrm{Npr}^{+/-}$, and $\mathrm{Npr}^{-/-}$Mice

\begin{tabular}{|c|c|c|c|}
\hline Genotype parameter & $\begin{array}{l}\mathrm{Npr}^{+/+} \text {mice } \\
(n=10)\end{array}$ & $\begin{array}{l}\mathrm{Npr}^{+/-} \text {mice } \\
(n=14)\end{array}$ & $\begin{array}{l}N_{p r 2^{-/}} \text {mice } \\
(n=8)\end{array}$ \\
\hline White blood cells, $\times 10^{9} / \mathrm{L}$ & $8.9 \pm 0.6$ & $7.5 \pm 0.5$ & $8.4 \pm 0.8$ \\
\hline Lymphocytes, $\times 10^{9} / \mathrm{L}$ & $8.8 \pm 0.7$ & $7.4 \pm 0.5$ & $7.5 \pm 0.7$ \\
\hline Neutrophils, $\times 10^{9} / \mathrm{L}$ & $0.48 \pm 0.07$ & $0.44 \pm 0.07$ & $0.57 \pm 0.11$ \\
\hline Monocytes, $\times 10^{9} / \mathrm{L}$ & $0.23 \pm 0.05$ & $0.16 \pm 0.02$ & $0.21 \pm 0.03$ \\
\hline Red blood cells, $\times 10^{9} / \mathrm{L}$ & $10.8 \pm 0.4$ & $10.8 \pm 0.1$ & $10.8 \pm 0.2$ \\
\hline Platelets, $\times 10^{9} / \mathrm{L}$ & $595 \pm 50$ & $578 \pm 22$ & $484 \pm 38^{*}$ \\
\hline Hematocrit, \% & $46.6 \pm 1.3$ & $46.0 \pm 0.6$ & $46.4 \pm 1.1$ \\
\hline Hemoglobin, $\mathrm{g} / \mathrm{dL}$ & $15.2 \pm 0.4$ & $15.2 \pm 0.2$ & $15.7 \pm 0.1$ \\
\hline Plateletcrit, \% & $0.39 \pm 0.03$ & $0.38 \pm 0.02$ & $0.31 \pm 0.02$ \\
\hline Mean corpuscular volume, $\mathrm{fL}$ & $43.7 \pm 0.3$ & $43.1 \pm 0.3$ & $43.3 \pm 0.7$ \\
\hline Mean corpuscular hemoglobin, pg & $14.2 \pm 0.3$ & $14.3 \pm 0.3$ & $14.7 \pm 0.3$ \\
\hline Mean corpuscular hemoglobin concentration, $\mathrm{g} / \mathrm{dL}$ & $32.7 \pm 0.9$ & $33.2 \pm 0.8$ & $34.0 \pm 0.8$ \\
\hline Red blood cell distribution width, $\%$ & $18.3 \pm 0.1$ & $18.2 \pm 0.1$ & $18.6 \pm 0.3$ \\
\hline Mean platelet volume, $\mathrm{fL}$ & $6.5 \pm 0.1$ & $6.3 \pm 0.1$ & $6.3 \pm 0.1$ \\
\hline Platelet distribution width, $\%$ & $30.0 \pm 0.3$ & $29.4 \pm 0.2$ & $30.0 \pm 0.5$ \\
\hline
\end{tabular}

Parameters are shown as means \pm SEM.

${ }^{\star} P<0.05$ versus $\mathrm{Npr}{ }^{+/+}$.

$\mathrm{Npr}^{+/+}$, Npr2 wild type; Npr2 ${ }^{+/-}, \mathrm{Npr2}$ heterozygous; Npr2 ${ }^{-/-}$, Npr2 knockout.

\section{Results}

\section{Characterization of the Npr2 ${ }^{-/-}$Mouse Reveals a Significant Kidney Phenotype}

The importance of the Npr2 gene in the regulation of body weight was confirmed (Supplemental Figure S1A). A significant reduction in left ventricular mass and anterior wall diameter in systole was also observed in small $\mathrm{Npr}^{-1-}$ mice compared with their littermates (Supplemental Table S1). However, reductions in stroke volume, left ventricular anterior wall diameter, internal diameter, and posterior wall diameter in diastole were found in $\mathrm{Npr}^{-1-}$ compared with $\mathrm{Npr}^{+/+}$or $\mathrm{Npr}^{+/-}$mice (Supplemental Table S1). Relative kidney weight/body weight, but not to heart weight, was increased in $\mathrm{Npr}^{-1-}$ mice after $1 \% \mathrm{NaCl}$ intake for 2 weeks (Supplemental Figure S1, B-D). The most prominent changes were in the kidneys of the $\mathrm{Npr}^{-/-}$mice
(Figure 1B). Specifically, higher blood cell deposits were observed in the renal papilla of $\mathrm{Npr}^{-1-}$ mice (Figure 1, B and $\mathrm{D})$. There was an increase in papilla cell nuclear number in relation to $\mathrm{Npr} 2$ gene depletion (Figure 1, B and C). The renal cortex histomorphometry was similar across $\mathrm{Npr} 2$ genotypes (data not shown). The increased nuclei and red blood cell deposits suggest an inflammatory and prothrombotic environment in kidneys of $\mathrm{Npr}^{-/-}$mice.

\section{Low Platelet Numbers in the Peripheral Blood in} $\mathrm{Npr}^{-/-}$Mice

Alterations in circulating cells could lead to blood congestion in the kidneys. $N p r 2^{-/-}$mice had normal numbers of white and red blood cells as well as other rheological parameters in the peripheral blood (Table 1). There were significantly lower (approximately 20\%)

Table 2 Hemodynamic Changes across $\mathrm{Npr}^{+/+}, \mathrm{Npr}^{+/-}$, and $\mathrm{Npr}^{-/-}$Mice after $1 \% \mathrm{NaCl}$ Intake for 2 Weeks

\begin{tabular}{|c|c|c|c|c|}
\hline Parameter & $\begin{array}{l}\text { Genotype } \\
\text { group }\end{array}$ & $\mathrm{Npr}^{+/+}$mice & $\mathrm{Npr}^{+/-}$mice & Npr2 ${ }^{-/-}$mice \\
\hline Systolic BP, mmHg & Baseline & $98 \pm 4$ & $97 \pm 7$ & $91 \pm 4$ \\
\hline \multirow[t]{2}{*}{ Diastolic BP, mmHg } & Baseline & $66 \pm 5$ & $71 \pm 5$ & $66 \pm 3$ \\
\hline & $1 \% \mathrm{NaCl}$ & $62 \pm 2$ & $65 \pm 2$ & $65 \pm 5$ \\
\hline Pulse pressure, $\mathrm{mmHg}$ & Baseline & $33 \pm 4$ & $26 \pm 2$ & $25 \pm 1$ \\
\hline & $1 \% \mathrm{NaCl}$ & $76 \pm 2$ & $79 \pm 2$ & $76 \pm 6$ \\
\hline \multirow[t]{2}{*}{ Heart rate, beats/minute } & Baseline & $515 \pm 56$ & $490 \pm 54$ & $483 \pm 45$ \\
\hline & $1 \% \mathrm{NaCl}$ & $463 \pm 51$ & $443 \pm 39$ & $462 \pm 15$ \\
\hline
\end{tabular}

Parameters are shown as means \pm SEM. $n=3$ to 5 per group.

$\mathrm{BP}$, blood pressure; $\mathrm{Npr2}^{+/+}$, Npr2 wild type; $\mathrm{Npr2}^{+/-}, \mathrm{Npr2}$ heterozygous; $\mathrm{Npr2}^{-/-}$, Npr2 knockout. 

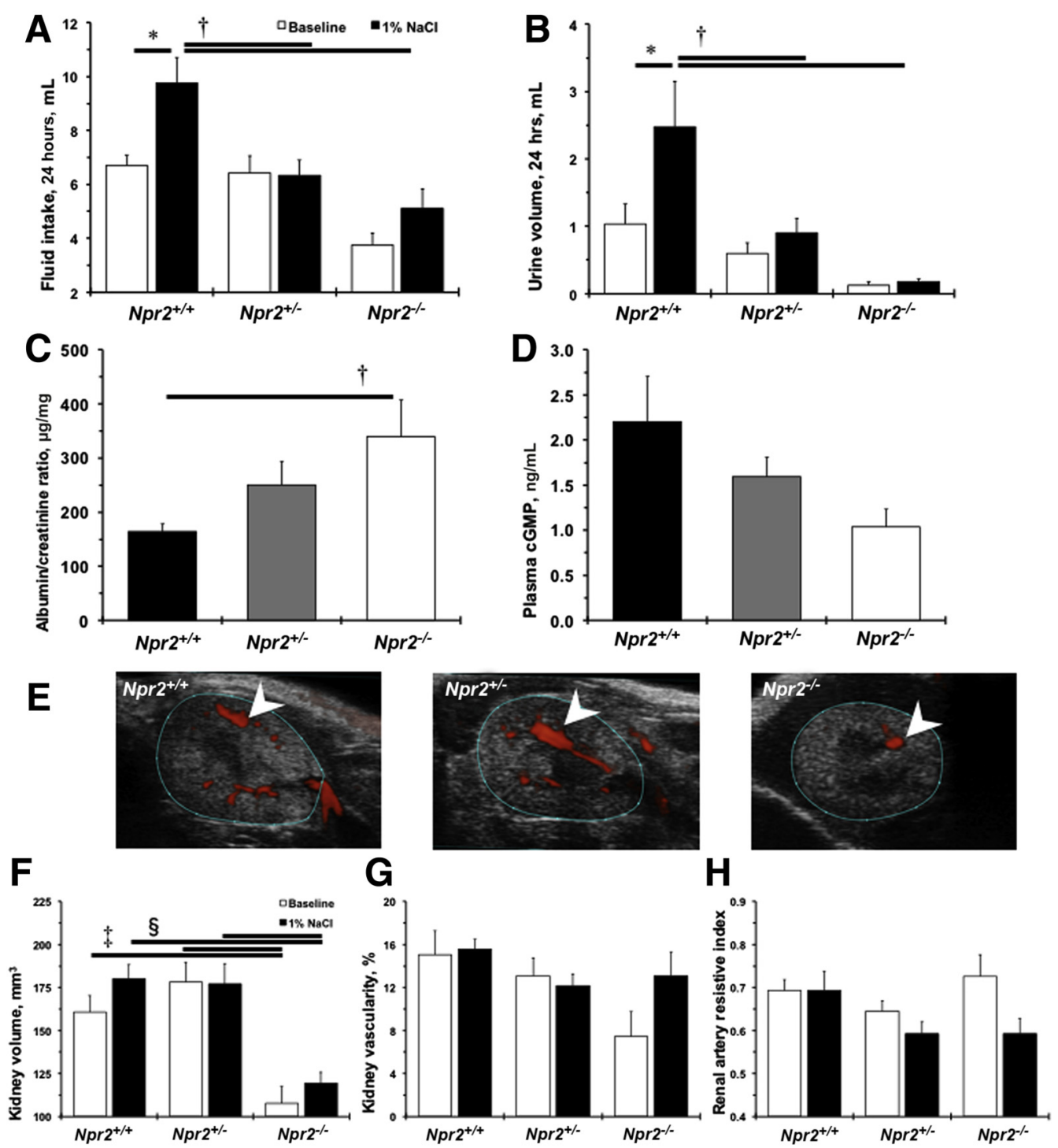

Figure 2 Lack of Npr2 worsens kidney dysfunction in response to salt. A: Fluid intake for 24 hours across Npr2 mice. B: Urine volume for 24 hours across Npr2 mice. White bars are baseline values. Black bars are values after 2 weeks of intake of $1 \% \mathrm{NaCl}$ in drinking water. $\mathbf{C}$ and $\mathbf{D}$ : A ratio of urine albumin/plasma creatinine (C) and plasma cGMP (D) across Npr2 genotypes after 2 weeks of $1 \% \mathrm{NaCl}$ intake in drinking water. Black bars are $\mathrm{Npr2}$ wild-type (Npr2 ${ }^{+/+}$) mice. Gray bars are Npr2 heterozygous $\left(\mathrm{Npr}^{+/-}\right)$mice. White bars are Npr2 knockout $\left(\mathrm{Npr}^{-/-}\right)$mice. E: Representative ultrasound images of a transverse plane of kidneys across Npr2 mice. Blue outlined areas define kidney boundaries. White arrowheads point to vascularity. F: Kidney volumes based on 3-dimensional (3D) imaging of the kidneys across Npr2 genotypes. G: Percentages of the kidney vasculature based on 3D imaging of the kidneys across Npr2 genotypes. H: Renal artery resistive index based on ultrasound imaging across Npr2 genotypes. White bars are baseline values. Black bars are values after 2 weeks of $1 \%$ $\mathrm{NaCl}$ intake in drinking water. Data are expressed as means \pm SEM. $n=7$ to 11 per group (A, B, and $\mathbf{F}-\mathbf{G}) ; n=5$ to 9 per group (C and $\mathbf{D})$. ${ }^{*} P<0.05$ versus $\mathrm{Npr}^{+/+}$(baseline); ${ }^{\dagger} P<0.05$ versus Npr2 ${ }^{+/+}(1 \% \mathrm{NaCl}){ }^{\ddagger}{ }^{\ddagger} P<0.05$ versus $\mathrm{Npr} 2^{-/-}$(baseline); ${ }^{\S} P<0.05$ versus Npr2 ${ }^{-/-}(1 \% \mathrm{NaCl})$.

platelet numbers in the peripheral blood of $\mathrm{Npr}^{-1-}$ compared with $\mathrm{Npr}^{+/+}$mice (Table 1). However, a similar distribution of megakaryocytes in the bone marrow indicates normal platelet development regardless of $\mathrm{Npr} 2$ genotype (Supplemental Figure S2). These data suggest that lack of $N p r 2$ results in a small reduction of platelets in the peripheral blood.

\section{Kidney Dysfunction after Salt Load in $\mathrm{Npr}^{-/-}$Mice}

$\mathrm{Npr} 2$ was discovered as a candidate gene for $\mathrm{BP}$ variation after $1 \% \mathrm{NaCl}$ intake in a cross between $\mathrm{C} 57 \mathrm{BL} / 6 \mathrm{~J}$ and $\mathrm{A} / \mathrm{J}$ inbred mouse strains. ${ }^{13}$ No differences were observed in BP or heart rate among $\mathrm{Npr} 2$ mice genotypes at baseline or after giving them $1 \% \mathrm{NaCl}$ for 2 weeks (Table 2). Two weeks of $1 \% \mathrm{NaCl}$ water doubled fluid intake and urination in $\mathrm{Npr}^{+/+}$ mice (Figure 2, A and B). These functional responses to $1 \%$ $\mathrm{NaCl}$ were diminished in $\mathrm{Npr}^{+/-}$and $\mathrm{Npr}^{-/-}$mice (Figure 2, $\mathrm{A}$ and B). Significant albuminuria was detected in $\mathrm{Npr}^{-/-}$ compared with $\mathrm{Npr}^{+/+}$mice after $1 \% \mathrm{NaCl}$ (Figure 2C). Plasma levels of cGMP did not reach statistical significance between $\mathrm{Npr}^{-/-}$and $\mathrm{Npr}^{+/+}$mice after 2 weeks of $1 \% \mathrm{NaCl}$ intake (Figure 2D). Ultrasound measurements revealed smaller kidney volumes in $\mathrm{Npr}^{-/-}$mice compared with $\mathrm{Npr}^{+/+}$and 

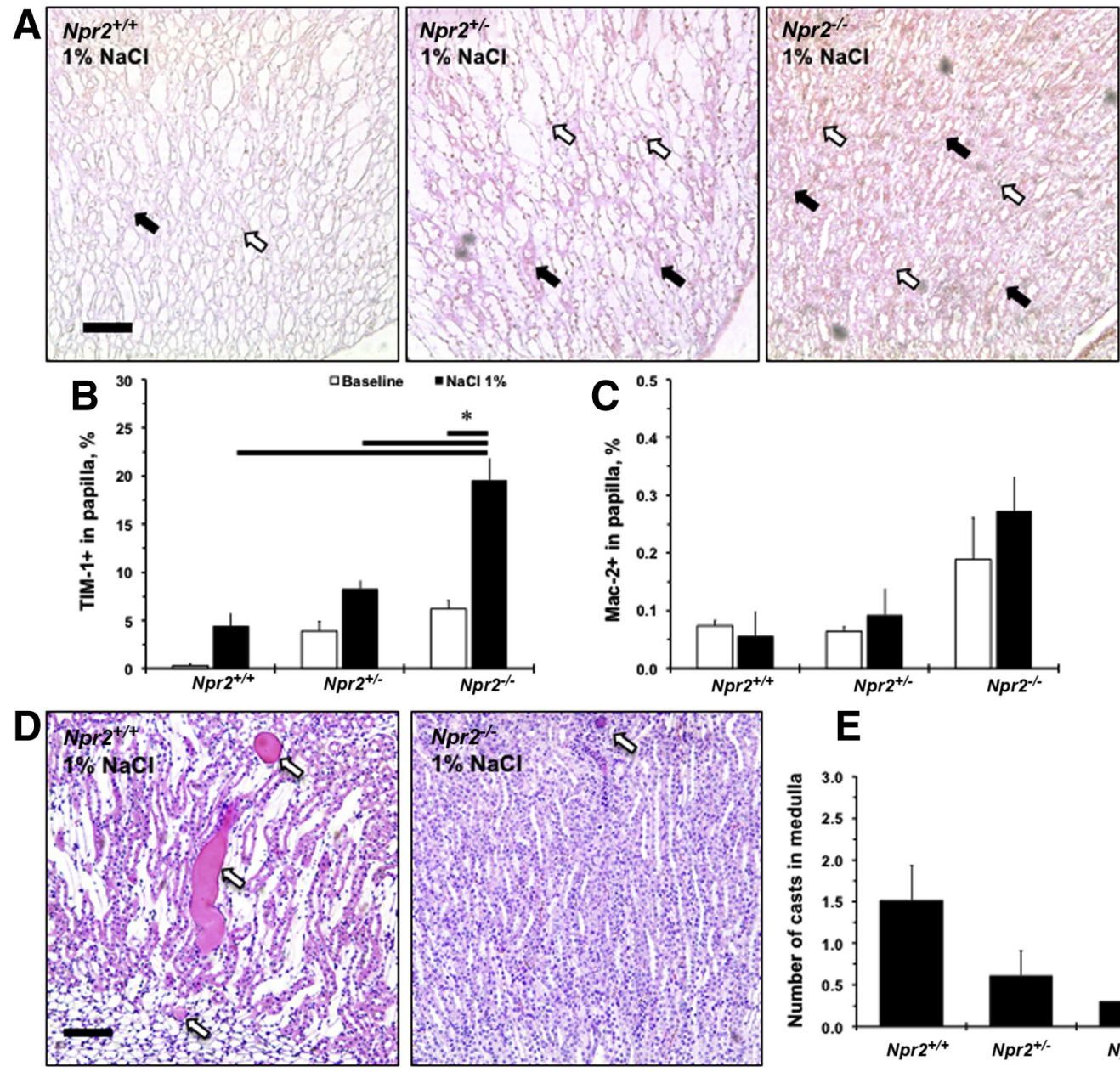

E
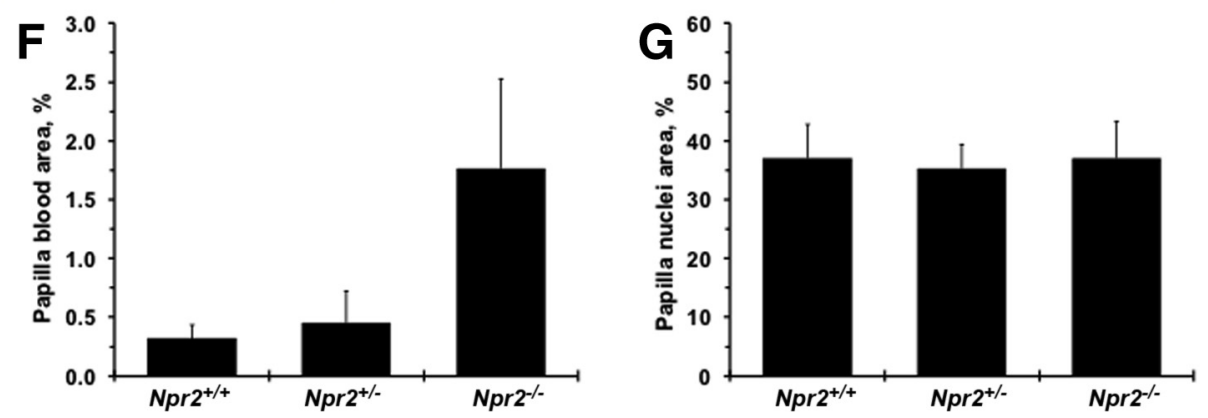

Figure 3 Histologic evaluation of renal papillary injury across Npr2 genotypes in response to salt. A: Representative images of double-stained [macrophage surface glycoproteins binding to galectin-3 (Mac-2) and T-cell Ig and mucin domain 1 (TIM-1)] kidney papilla across Npr2 genotypes after $1 \%$ NaCl intake in drinking water for 2 weeks. White arrows show Mac- $2^{+}$cells (brown). Black arrows show TIM-1 ${ }^{+}$staining (pink). Counterstain is green. B and C: Quantitative analysis of the TIM-1 (B) and Mac-2 (C) expression in the renal papilla in Npr2 mice. D: Representative images of hematoxylin and eosin-stained renal medulla of $\mathrm{Npr} 2$ wild-type $\left(\mathrm{Npr}^{+/+}\right)$and $\mathrm{Npr} 2$ knockout $\left(\mathrm{Npr}^{-/-}\right)$mice after $1 \% \mathrm{NaCl}$ intake in drinking water for 2 weeks. White arrows point to protein casts. E: Quantitative analysis of protein casts in the renal medulla in Npr2 mice. No protein casts were detected at baseline. F: Quantification of blood in renal papilla in Npr2 mice. G: Quantification of nuclei area in renal papilla in Npr2 mice. White bars are baseline values. Black bars are values after 2 weeks of $1 \%$ NaCl intake in drinking water. Data are expressed as means \pm SEM. $n=3$ per group (B and $\mathbf{C}) ; n=3$ to 5 per group $(\mathbf{E}-\mathbf{G})$. ${ }^{*} P<0.05$ versus Npr2 ${ }^{-/-}(1 \%$ NaCl). Scale bars $=100 \mu \mathrm{m}(\mathbf{A}$ and $\mathbf{D}) . \mathrm{Npr}^{+/-}$, Npr2 heterozygous.

$\mathrm{Npr}^{+/-}$mice at baseline (Figure 2, E-G). Treatment with $1 \%$ $\mathrm{NaCl}$ water had little effect on kidney volume or renal artery hemodynamics in $\mathrm{Npr} 2$ mice (Figure 2, F-H, and Supplemental Table S2). Taken together, these data show that the $N p r 2$ gene is protective against kidney dysfunction in response to a $1 \%$ salt load.
Deletion of Npr2 Gene Leads to Kidney Injury after Salt Intake

Expression of an epithelial damage marker, TIM-1, was weak and tended to increase after $1 \% \mathrm{NaCl}$ in renal papilla in $N p r 2^{+/+}$mice $(P<0.1)$ (Figure 3, A and B). The strongest 


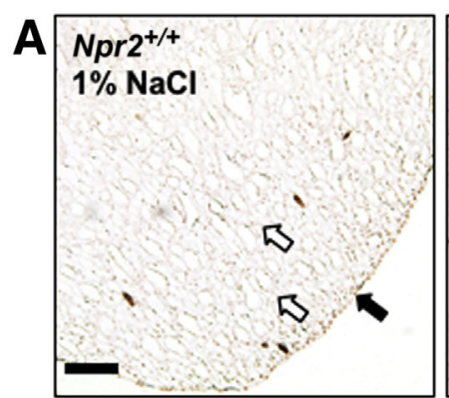

B

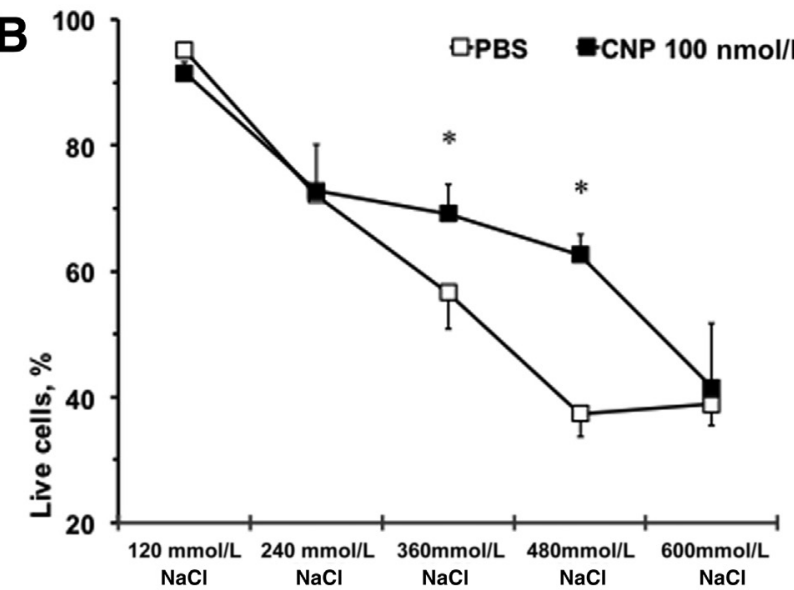

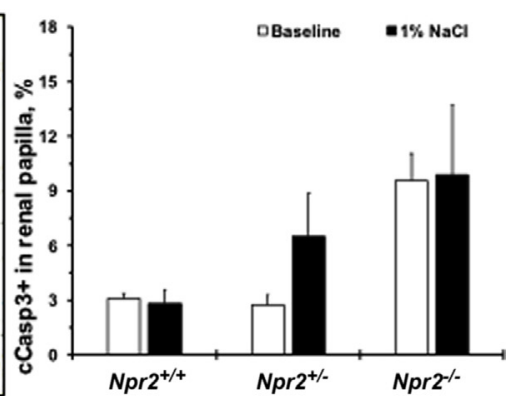
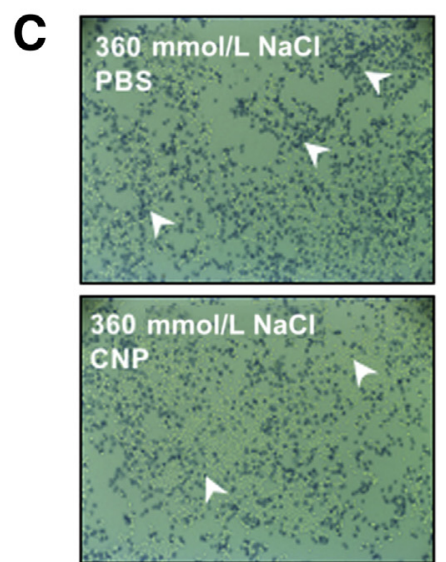
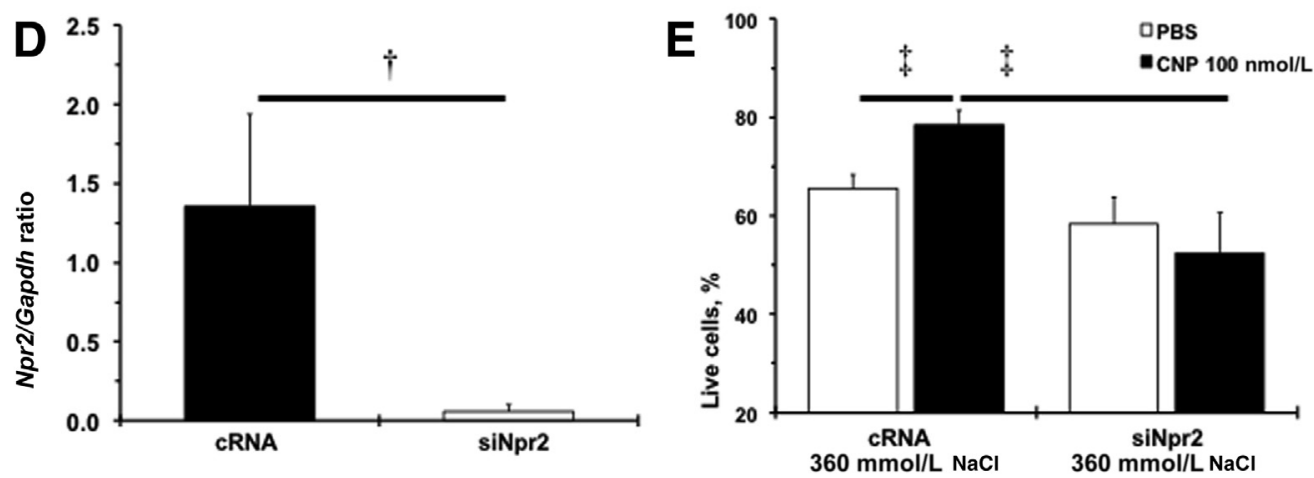

Figure 4 Npr2 protects renal epithelial cells against apoptosis in response to high salt. A: Representative images of cleaved caspase 3 staining (cCasp3; brown; black arrows) of renal papilla of Npr2 wild-type $\left(\mathrm{Npr}^{+/+}\right)$and $\mathrm{Npr} 2$ knockout $\left(\mathrm{Npr}^{-/-}\right)$mice after $1 \% \mathrm{NaCl}$ intake in drinking water for 2 weeks. Counterstained nuclei are indicated by white arrows. Bar graph shows a quantitative analysis of cCasp 3 expression in the renal papilla across experimental mice. White bars are baseline values. Black bars are values after 2 weeks of $1 \% \mathrm{NaCl}$ intake in drinking water. B: C-type natriuretic peptide (CNP) protects $\mathrm{M}-1$ cells from higher concentrations of $\mathrm{NaCl}$ in the medium. White squares show phosphate-buffered saline (PBS) treatment. Black squares show CNP $(100 \mathrm{nmol} / \mathrm{L})$ treatment. C: Representative images of trypan blue staining (white arrowheads) of treated $\mathrm{M}-1 \mathrm{cells}$ at $360 \mathrm{mmol} / \mathrm{L} \mathrm{NaCl}$. D: Relative expression of Npr2 on gene silencing in M-1 cells. E: Npr2 depletion abolishes protective effects of CNP in M-1 cells at $360 \mathrm{mmol} / \mathrm{L} \mathrm{NaCl}$. White bars show PBS treatment. Black bars show CNP $(100 \mathrm{nmol} / \mathrm{L})$ treatment. Data are expressed as the means \pm SEM. $n=3$ per group $(\mathbf{A}$ and $\mathbf{B}) ; n=3$ to 4 per group (D and E). ${ }^{*} P<0.05$ versus PBS treatment; ${ }^{\dagger} P<0.05$ versus complementary RNA (CRNA); ${ }^{\ddagger} P<0.05$ versus cRNA (CNP, 100 nmol/L). Scale bar $=100 \mu \mathrm{m}(\mathbf{A})$. siNpr2, silencing of Npr2.

TIM-1 staining was in $\mathrm{Npr}^{-1-}$ after $1 \% \mathrm{NaCl}$ intake compared with $\mathrm{Npr}^{+/+}$and $\mathrm{Npr}^{+/-}$mice (Figure 3, A and B). There was a trend $(P<0.1)$ toward increased presence of Mac- $2^{+}$cells in the renal papilla in $\mathrm{Npr}^{-1-}$ mice after $\mathrm{NaCl}$ (Figure 3, A and C). Of interest, fewer protein casts were observed in the renal medulla of $\mathrm{Npr}^{-1-}$ mice compared with $\mathrm{Npr}^{+/-}$and $\mathrm{Npr}^{+/+}$mice after $\mathrm{NaCl}$ (Figure 3, D and E). In the renal papilla of $\mathrm{Npr}^{-1-}$ mice, there was a trend $(P<0.1)$ toward increased red blood cell aggregates after $\mathrm{NaCl}$ (Figure 3F). Finally, there were no differences in cell nuclei in renal papilla across $N p r 2$ genotypes after salt exposure (Figure 3G). Loss of the Npr2 gene causes renal papilla injury, which is exacerbated by salt.

\section{Protective Effects of the CNP/Npr2 Pathway in Renal Epithelial Cells}

Administration of the Npr2 ligand, CNP, was shown to reduce cell death in the medulla after kidney damage. ${ }^{27}$ Two weeks of $1 \% \mathrm{NaCl}$ tended $(P<0.1)$ to increase cleaved 

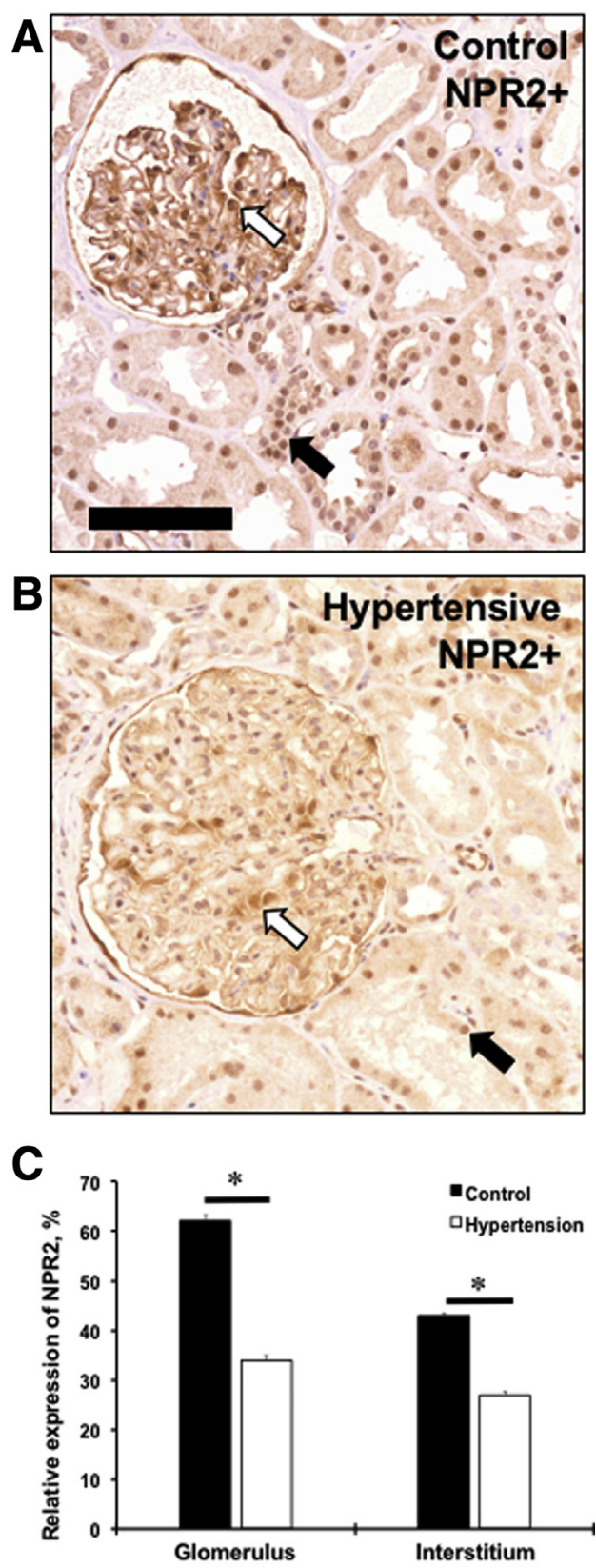

Figure 5 NPR2 expression is decreased in kidneys of hypertensive patients. A and B: Renal expression of NPR2 (brown staining) in control (A) and hypertensive (B) kidney samples. White arrows point to NPR2 ${ }^{+}$cells in glomerulus. Black arrows point to NPR2 ${ }^{+}$cells in interstitium. C: Quantification of NPR2 immunoreactivity in kidney compartments on $x$ axis. Values are expressed as means \pm SEM. $n=5$ per group (C). ${ }^{*} P<0.05$ versus control. Scale bar $=100 \mu \mathrm{m}(\mathbf{A}$ and $\mathbf{B})$.

caspase 3-positive cells at the tip of renal papilla in $\mathrm{Npr}^{+/-}$ and remained elevated in $\mathrm{Npr}^{-/-}$compared with $\mathrm{Npr}^{+/+}$ mice (Figure 4A). The number of apoptotic cells measured by cleaved caspase 3 immunohistochemistry within the renal cortex was similar across $\mathrm{Npr} 2$ genotypes (data not shown). Previous data showed that renal epithelial cells could withstand high levels of $\mathrm{NaCl}$ in vitro, which reflects the in vivo fivefold increase in osmolality from renal cortex to papilla. ${ }^{19,28}$ A significant reduction of survived M-1 cells to $40 \%$ with increased concentration of $\mathrm{NaCl}$ from 120 to 600 $\mathrm{mmol} / \mathrm{L}$ was observed (Figure 4B). However, pretreatment with CNP significantly increased numbers of surviving M-1 cells at 360 and $480 \mathrm{mmol} / \mathrm{L}$ of $\mathrm{NaCl}$ (Figure 4, B and C). $\mathrm{Npr} 2$ was expressed in M-1 cells, and $N p r 2$ siRNA drastically reduced its expression (Figure 4D). Knocking down of $\mathrm{Npr} 2$ gene through $\mathrm{Npr} 2$ siRNA abolished the protective effects of the CNP against $360 \mathrm{mmol} / \mathrm{L} \mathrm{NaCl}$-induced M-1 cell death (Figure 4E). These findings suggest that activation of Npr2 by CNP is important in protecting renal epithelial cells against high salt.

\section{NPR2 Expression Is Decreased in Human Hypertensive Kidney}

A human genetic study suggested that mutations in NPR2 gene are associated with essential hypertension. ${ }^{12}$ As in mouse kidneys, expression of the NPR2 was evident in the interstitial compartment with a greater intensity in a glomerular area of the normotensive human kidney (Figure 5, A and C). There was a significant decrease in relative expression of the NPR2 in hypertensive kidney compared with normotensive controls (Figure 5, B and C). Thus, a decreased expression of NPR2 in human disease supports our findings on the protective role of the receptor in kidney dysfunction in mice.

\section{Discussion}

A major finding in the present study is that the Npr2 gene prevents renal dysfunction by protecting renal papilla cells against salt-induced damage. A short-limbed dwarfism in $N p r 2^{-1-}$ mice in our colony was confirmed, as was originally reported. ${ }^{11}$ For the first time, we described a phenotype of blood cell deposits in renal papilla with a slight reduction of platelets in blood in $\mathrm{Npr}^{-/-}$mice. $\mathrm{Npr}^{-1-}$ and $\mathrm{Npr}^{+/-}$mice showed reduced diuresis, and $1 \% \mathrm{NaCl}$ in drinking water significantly worsened albuminuria and renal dysfunction in these mice. There was an increase in renal epithelial damage (TIM- $1^{+}$staining) with blood cell deposits and inflammatory cells $\left(\mathrm{Mac}^{+}{ }^{+}\right)$within renal papilla in mice with $\mathrm{Npr} 2$ depletion. Both $\mathrm{Npr}^{-/-}$and $\mathrm{Npr}^{+/-}$mice exhibited worse responses to salt, likely because of augmentation in cell death in renal papilla. In fact, there was a trend toward increased apoptotic cells (cleaved caspase 3 positive) near the tip of the renal papilla in $\mathrm{Npr}^{-1-}$ mice. A knockdown of the $N p r 2$ with siRNA in M-1 cells abolished beneficial effects of CNP after exposure to $360 \mathrm{mmol} / \mathrm{L}$ of $\mathrm{NaCl}$. Finally, significantly lower levels of NPR2 protein were detected in renal samples of hypertensive patients.

The NPR2 gene is associated with essential hypertension in the Japanese population in addition to a genetic link to a rare form of dwarfism. ${ }^{12}$ A study with a majority 
of European ancestry patients with coronary artery disease showed that a minor allele of NPR2 (rs 10758325) was significantly associated with a lower rate of cardiovascular outcomes but not with BP. ${ }^{29}$ Intriguingly, another report suggested that shorter individuals are more prone to cardiovascular disease than their taller counterparts. ${ }^{30} \mathrm{Npr} 2$ was implicated as a candidate gene within the Bpq3 locus in salt-induced BP variation in a mouse genetic cross between $\mathrm{C} 57 \mathrm{BL} / 6 \mathrm{~J}$ and $\mathrm{A} / \mathrm{J}$ inbred mouse strains. ${ }^{13}$ Recent studies with cell-specific gene targeting in mice or spontaneously hypertensive rats suggested that BP homeostasis is primarily regulated by $\mathrm{CNP}$ and $\mathrm{Npr} 3$ (not $\mathrm{Npr} 2$ ) that is produced by the endothelium. ${ }^{14,31,32} \mathrm{~A}$ genome-wide association study showed that genetic variations in NPPA, $N P P B$, and NPR3 genes affected BP, but not kidney dysfunction. ${ }^{33}$ Similar to the original findings after $\mathrm{Npr} 2$ deletion on $\mathrm{BP},{ }^{11}$ the same $\mathrm{BP}$ was also observed across all $N p r 2$ genotypes. In contrast, decreased expression of $\mathrm{Npr} 2$ was associated with renal kidney dysfunction, which was augmented by $1 \% \mathrm{NaCl}$ in drinking water. A recent report showed that a release of CNP from endothelial cells primarily relaxes precapillary arterioles and capillaries through activation of the Npr2/cGMP axis in pericytes. ${ }^{34}$ These data suggest additional roles for the CNP/Npr2 pathway in the autocrine regulation of renal epithelium that contribute to response to salt.

A decrease in diuresis was observed after $\mathrm{Npr} 2$ gene depletion, which correlated well with anatomic changes in renal medulla. These pathologic alterations in the kidney worsened after 2 weeks of $1 \% \mathrm{NaCl}$ intake. However, renal cortex appeared to be normal in $\mathrm{Npr}^{-1-}$ mice. The affected compartment of the kidney medulla, renal papilla, is responsible for transporting urine produced in the renal cortex to the cup-shaped cavity where the urine accumulates before passing through the ureter into the bladder. ${ }^{35}$ Sodium concentration gradually increases from the base to the tip of the renal pelvis. ${ }^{36}$ Dehydration of rats significantly increased $\mathrm{Na}^{+}$and urea in the interstitial fluid in renal papilla. ${ }^{28}$ An Npr2 gene-titration effect was also observed on fluid intake associated with dehydration, especially after $1 \% \mathrm{NaCl}$ intake in $\mathrm{Npr}^{+/-}$and $\mathrm{Npr} 2^{-/-}$mice. High levels of apoptosis in renal papilla in vivo and an increase in M-1 cell death in vitro with $\mathrm{Npr} 2$ depletion support the prosurvival effects of CNP/Npr2 signals in epithelial cells under high concentrations of $\mathrm{NaCl}$. It has been shown that renal epithelial cells resist elevated $\mathrm{Na}^{+}$compared with other cell types. ${ }^{19}$ In addition, the effects of Npr2 on platelet count may exacerbate epithelial apoptosis by increasing parenchymal bleeding in $\mathrm{Npr}^{-/-}$mice. The deposition of iron from red blood cells would increase reactive oxygen species, which could cause apoptosis. It is likely that reduced platelet count in $\mathrm{Npr}^{-I-}$ mice is due to increase in platelet clearance rather than a production issue as no expression of NPRs in human platelets has been reported. ${ }^{37}$ Herein, it was confirmed that $\mathrm{Npr} 2$ is a critical receptor for CNP-dependent renal protection against high salt.
Renal papilla has low blood supply, which might make it vulnerable to ischemia and necrosis. In fact, CNP administration inhibited oxidative and apoptotic pathways and ameliorated acute kidney injury in a rat model of renal ischemia/reperfusion injury. ${ }^{38}$ High concentrations of drugs and their metabolites in the renal medulla have been shown to contribute to renal papilla damage. ${ }^{39,40}$ For example, cisplatin is a potent chemotherapeutic agent but is highly toxic to renal tubular cells. ${ }^{41}$ Administration of cisplatin to rats induced nephropathy, which was accompanied by a significant reduction in the levels of cGMP in renal papilla and decreased expression of Nprs. ${ }^{42}$ A coadministration of cisplatin with CNP reduced cisplatin-induced nephropathy in mice. ${ }^{27}$ The authors found that CNP prevented decline in Npr2 expression with significant reduction of markers of renal tubular damage (apoptosis and inflammation) compared with mice that received cisplatin alone. In this study, depletion of $\mathrm{Npr} 2$ significantly increased apoptosis, inflammation, and tubular injury after $1 \% \mathrm{NaCl}$ intake. These findings suggest that CNP and Npr2 are important survival factors for renal papillary cells, especially in response to pathophysiological insults to the kidney medulla.

One of the limitations of this study is related to the confounding effects of the small size of mice lacking $N p r 2$. For example, heart and kidney sizes were significantly smaller. Furthermore, BP could be directly measured under anesthesia only, which was lower compared with $\mathrm{BP}$ values in response to $1 \% \mathrm{NaCl}$ in conscious C57BL/6J mice. ${ }^{13}$ Nevertheless, these findings are in line with an original report suggesting a minimal role for $N p r 2$ in BP increase after salt. ${ }^{11}$ In contrast, renal phenotypes were augmented not only in $\mathrm{Npr}^{-/-}$but also in $\mathrm{Npr}^{+/-}$mice compared with $\mathrm{Npr}^{+/+}$littermates after salt intake. Although M-1 cells were originally derived from cortical collecting ducts of mouse kidney, these cells are accepted as a model for studies of renal epithelial cells. Known profiles of the expression of Npr2 within kidneys make our experiments relevant to functions of renal epithelium. ${ }^{15,16}$ Although limited data are presented in human kidneys, a lower immunoreactivity to NPR2 protein in hypertensive patients supports a paradigm of decreased expression of the receptor under pathologic conditions. ${ }^{42}$ Future studies evaluating CNP and NPR2 are warranted in humans with renal damage.

In summary, the present study is the first to report on the importance of the Npr2 gene in kidney function. These findings highlight effects of CNP/Npr2-mediated protection of renal papilla cells under high concentrations of $\mathrm{NaCl}$. These results could lead to new therapeutic approaches in patients with salt-sensitive hypertension and other kidney disorders.

\section{Acknowledgments}

We thank Qian Zhou and Kathy Donlon for help with animal handling and histologic processing of mouse kidneys. 
V.A.K. and B.C.B. conceived and managed the project; G.J.D., B.Q., L.L., D.M.M., S.K.T., and V.A.K. performed experiments; G.J.D., B.Q., D.M.M., and V.A.K. analyzed data; G.J.D., B.Q., and V.A.K. prepared figures; C.N.M., J.C., M.M.D., and C.Y. interpreted results; G.J.D. wrote the manuscript; G.J.D., L.L., D.M.M., C.N.M., J.C., M.M.D., C.Y., B.C.B., and V.A.K. edited and revised the manuscript; and G.J.D., B.Q., L.L., D.M.M., S.K.T., C.N.M., J.C., M.M.D., C.Y., B.C.B., and V.A.K. approved the final version of the manuscript.

\section{Supplemental Data}

Supplemental material for this article can be found at http://doi.org/10.1016/j.ajpath.2019.05.020.

\section{References}

1. Kinnunen P, Vuolteenaho O, Ruskoaho H: Mechanisms of atrial and brain natriuretic peptide release from rat ventricular myocardium: effect of stretching. Endocrinology 1993, 132:1961-1970

2. Rosenzweig A, Seidman CE: Atrial natriuretic factor and related peptide hormones. Annu Rev Biochem 1991, 60:229-255

3. Brenner BM, Ballermann BJ, Gunning ME, Zeidel ML: Diverse biological actions of atrial natriuretic peptide. Physiol Rev 1990, 70: 665-699

4. Inagami $\mathrm{T}$ : Atrial natriuretic factor. $\mathrm{J}$ Biol Chem 1989, 264: 3043-3046

5. de Bold AJ: Atrial natriuretic factor: a hormone produced by the heart. Science 1985, 230:767-770

6. Suga S-I, Nakao K, Itoh H, Komatsu Y, Ogawa Y, Hama N, Imura H: Endothelial production of C-type natriuretic peptide and its marked augmentation by transforming growth factor B. J Clin Invest 1992, 90:1145-1149

7. Matsukawa N, Grzesik WJ, Takahashi N, Pandey KN, Pang S, Yamauchi M, Smithies O: The natriuretic peptide clearance receptor locally modulates the physiological effects of the natriuretic peptide system. Proc Natl Acad Sci U S A 1999, 96:7403-7408

8. Suga S, Nakao K, Hosoda K, Mukoyama M, Ogawa Y, Shirakami G, Arai H, Saito Y, Kambayashi Y, Inouye K, Imura H: Receptor selectivity of natriuretic peptide family, atrial natriuretic peptide, brain natriuretic peptide, and C-type natriuretic peptide. Endocrinology 1992, 130:229-239

9. Potter LR, Abbey-Hosch S, Dickey DM: Natriuretic peptides, their receptors, and cyclic guanosine monophosphate-dependent signaling functions. Endocr Rev 2006, 27:47-72

10. Bartels CF, Bukulmez H, Padayatti P, Rhee DK, van RavenswaaijArts C, Pauli RM, Mundlos S, Chitayat D, Shih LY, Al-Gazali LI, Kant S, Cole T, Morton J, Cormier-Daire V, Faivre L, Lees M, Kirk J, Mortier GR, Leroy J, Zabel B, Kim CA, Crow Y, Braverman NE, van den Akker F, Warman ML: Mutations in the transmembrane natriuretic peptide receptor NPR-B impair skeletal growth and cause acromesomelic dysplasia, type Maroteaux. Am J Hum Genet 2004 , $75: 27-34$

11. Tamura N, Doolittle LK, Hammer RE, Shelton JM, Richardson JA, Garbers DL: Critical roles of the guanylyl cyclase B receptor in endochondral ossification and development of female reproductive organs. Proc Natl Acad Sci U S A 2004, 101:17300-17305

12. Rehemudula D, Nakayama T, Soma M, Takahashi Y, Uwabo J, Sato M, Izumi Y, Kanmatsuse K, Ozawa Y: Structure of the type B human natriuretic peptide receptor gene and association of a novel microsatellite polymorphism with essential hypertension. Circ Res 1999, 84:605-610
13. Sugiyama F, Churchill GA, Higgins DC, Johns C, Makaritsis KP, Gavras H, Paigen B: Concordance of murine quantitative trait loci for salt-induced hypertension with rat and human loci. Genomics 2001, 71:70-77

14. Moyes AJ, Khambata RS, Villar I, Bubb KJ, Baliga RS, Lumsden NG, Xiao F, Gane PJ, Rebstock AS, Worthington RJ, Simone MI, Mota F, Rivilla F, Vallejo S, Peiro C, Sanchez Ferrer CF, Djordjevic S, Caulfield MJ, MacAllister RJ, Selwood DL, Ahluwalia A, Hobbs AJ: Endothelial C-type natriuretic peptide maintains vascular homeostasis. J Clin Invest 2014, 124:4039-4051

15. Terada Y, Tomita K, Nonoguchi H, Yang T, Marumo F: PCR localization of C-type natriuretic peptide and B-type receptor mRNAs in rat nephron segments. Am J Physiol 1994, 267:F215-F222

16. Dean AD, Vehaskari VM, Ritter D, Greenwald JE: Distribution and regulation of guanylyl cyclase type $\mathrm{B}$ in the rat nephron. Am J Physiol 1996, 270:F311-F318

17. Committee for the Update of the Guide for the Care and Use of Laboratory AnimalsNational Research Council: Guide for the Care and Use of Laboratory Animals: Eighth Edition. Washington, DC, National Academies Press, 2011

18. Ilatovskaya DV, Chubinskiy-Nadezhdin V, Pavlov TS, Shuyskiy LS, Tomilin V, Palygin O, Staruschenko A, Negulyaev YA: Arp2/3 complex inhibitors adversely affect actin cytoskeleton remodeling in the cultured murine kidney collecting duct M-1 cells. Cell Tissue Res 2013, 354:783-792

19. Uchida S, Green N, Coon H, Triche T, Mims S, Burg M: High NaCl induces stable changes in phenotype and karyotype of renal cells in culture. Am J Physiol 1987, 253:C230-C242

20. Batchu SN, Hughson A, Wadosky KM, Morrell CN, Fowell DJ, Korshunov VA: Role of Axl in T-lymphocyte survival in salt-dependent hypertension. Arterioscler Thromb Vasc Biol 2016, 36:1638-1646

21. Batchu SN, Dugbartey GJ, Wadosky KM, Mickelsen DM, Ko KA, Wood RW, Zhao Y, Yang X, Fowell DJ, Korshunov VA: Innate immune cells are regulated by Axl in hypertensive kidney. Am J Pathol 2018, 188:1794-1806

22. Batchu SN, Xia J, Ko KA, Doyley MM, Abe J, Morrell CN, Korshunov VA: Axl modulates immune activation of smooth muscle cells in vein graft remodeling. Am J Physiol Heart Circ Physiol 2015, 309:H1048-H1058

23. Varghese JJ, Schmale IL, Mickelsen D, Hansen ME, Newlands SD, Benoit DSW, Korshunov VA, Ovitt CE: Localized delivery of amifostine enhances salivary gland radioprotection. J Dent Res 2018. 22034518767408

24. Breyer MD, Bottinger E, Brosius FC 3rd, Coffman TM, Harris RC, Heilig CW, Sharma K: Amdcc: mouse models of diabetic nephropathy. J Am Soc Nephrol 2005, 16:27-45

25. Harms JF, Budgeon LR, Christensen ND, Welch DR: Maintaining GFP tissue fluorescence through bone decalcification and long-term storage. Biotechniques 2002, 33:1197-1200

26. Gerloff J, Korshunov VA: Immune modulation of vascular resident cells by Axl orchestrates carotid intima-media thickening. Am J Pathol 2012, 180:2134-2143

27. Kimura T, Nojiri T, Hosoda H, Ishikane S, Shintani Y, Inoue M, Miyazato M, Okumura M, Kangawa K: Protective effects of C-type natriuretic peptide on cisplatin-induced nephrotoxicity in mice. Cancer Chemother Pharmacol 2015, 75:1057-1063

28. Lee J, Williams PG: Changes of sodium and urea concentrations in the renal papillary interstitial fluid on dehydration of rats. J Physiol 1971, 218:195-204

29. Ellis KL, Newton-Cheh C, Wang TJ, Frampton CM, Doughty RN, Whalley GA, Ellis CJ, Skelton L, Davis N, Yandle TG, Troughton RW, Richards AM, Cameron VA: Association of genetic variation in the natriuretic peptide system with cardiovascular outcomes. J Mol Cell Cardiol 2011, 50:695-701

30. Nelson CP, Hamby SE, Saleheen D, Hopewell JC, Zeng L, Assimes TL, et al: Genetically determined height and coronary artery disease. N Engl J Med 2015, 372:1608-1618 
31. Nakao K, Kuwahara K, Nishikimi T, Nakagawa Y, Kinoshita H, Minami T, Kuwabara Y, Yamada C, Yamada Y, Tokudome T, NagaiOkatani C, Minamino N, Nakao YM, Yasuno S, Ueshima K, Sone M, Kimura T, Kangawa K, Nakao K: Endothelium-derived c-type natriuretic peptide contributes to blood pressure regulation by maintaining endothelial integrity. Hypertension 2017, 69:286-296

32. Caniffi C, Cerniello FM, Gobetto MN, Sueiro ML, Costa MA, Arranz C: Vascular tone regulation induced by C-type natriuretic peptide: differences in endothelium-dependent and -independent mechanisms involved in normotensive and spontaneously hypertensive rats. PLoS One 2016, 11:e167817

33. International Consortium for Blood Pressure Genome-Wide Association Studies, Ehret GB, Munroe PB, Rice KM, Bochud M, Johnson AD, et al: Genetic variants in novel pathways influence blood pressure and cardiovascular disease risk. Nature 2011, 478:103-109

34. Spiranec K, Chen W, Werner F, Nikolaev VO, Naruke T, Koch F, Werner A, Eder-Negrin P, Dieguez-Hurtado R, Adams RH, Baba HA, Schmidt H, Schuh K, Skryabin BV, Movahedi K, Schweda F, Kuhn M: Endothelial C-type natriuretic peptide acts on pericytes to regulate microcirculatory flow and blood pressure. Circulation 2018, 138:494-508

35. Schmidt-Nielsen B, Schmidt-Nielsen B: On the function of the mammalian renal papilla and the peristalsis of the surrounding pelvis. Acta Physiol (Oxf) 2011, 202:379-385
36. Bargman J, Leonard SL, McNeely E, Robertson C, Jamison RL: Examination of transepithelial exchange of water and solute in the rat renal pelvis. J Clin Invest 1984, 74:1860-1870

37. Gambaryan S, Subramanian H, Rukoyatkina N, Herterich S, Walter U: Soluble guanylyl cyclase is the only enzyme responsible for cyclic guanosine monophosphate synthesis in human platelets. Thromb Haemost 2013, 109:973-975

38. Jin X, Zhang Y, Li X, Zhang J, Xu D: C-type natriuretic peptide ameliorates ischemia/reperfusion-induced acute kidney injury by inhibiting apoptosis and oxidative stress in rats. Life Sci 2014, 117: $40-45$

39. Jung DC, Kim SH, Jung SI, Hwang SI, Kim SH: Renal papillary necrosis: review and comparison of findings at multi-detector row CT and intravenous urography. Radiographics 2006, 26: $1827-1836$

40. Kolaja GJ, Packwood WH, Bell RR, Ratke CC, Stout CL: Renal papillary necrosis and urinary protein alterations induced in Fischer344 rats by D-ormaplatin. Toxicol Pathol 1994, 22:29-38

41. dos Santos NA, Carvalho Rodrigues MA, Martins NM, dos Santos AC: Cisplatin-induced nephrotoxicity and targets of nephroprotection: an update. Arch Toxicol 2012, 86:1233-1250

42. Kim CS, Choi JS, Park JW, Bae EH, Ma SK, Lee J, Kim SW: Altered regulation of nitric oxide and natriuretic peptide system in cisplatininduced nephropathy. Regul Pept 2012, 174:65-70 